\title{
Adult Daughter-Mother Attachment: Psychometric Properties of Turkish Version of Adult Attachment Scale *
}

\author{
Meltem ANAFARTA ŞENDAĞ $* *$
}

\author{
Funda KUTLU ***
}

\begin{abstract}
The present study aims to assess the psychometric qualities of the Turkish version of the Adult Attachment Scale (AAS) assessing adult daughter's current attachment to their elderly mother. In total, 560 women with the mean age of 39.6 have participated. Parallel to the original study, exploratory factor analysis was conducted with adult daughters $(N=304)$ who were providing instrumental help to their mothers regularly. Results yielded 2 correlated factors (secure base and safe haven). Confirmatory factor analysis revealed that the factor structure is applicable to the adult daughters who were not providing regular help to their mothers $(N=256)$. Measurement invariance was established across two groups constructed in terms of the presence of instrumental help provided to the elderly mothers by their adult daughters. Internal consistency and 6-month stability for the scale are satisfactory. Further evidence for convergent and concurrent validity has been supported by presenting a positive correlation of AAS with the level of significance of the mother in the adult daughter's attachment hierarchy as compared to other attachment figures, levels of quality of the current relationship and the frequency of contact with the mother. Results are discussed in terms of AAS's appropriateness for Turkish culture and possible contribution in an understanding attachment to a parent in late adulthood, a critical emerging need for the aging world.
\end{abstract}

Key Words: Attachment, adult daughter, elderly mother.

\section{INTRODUCTION}

Given that the global population has aged at an unprecedented rate and that $28 \%$ of the European population will be over 65 in 30 years (He, Goodkind \& Kowall, 2016), it becomes a critical and urgent task to question and to improve our scientific understanding of aging and old age. The major reasons for such global demographic change are reported as being the aging of "baby boom" generation and decreased fertility rates (Bloom, Canning \& Lubet, 2015; Lowenstein, 2005; Trommsdorff \& Nauck, 2006). In addition, increasing life expectancy due to development in medicine and preventive health care practices is also mentioned as an important reason for the increase in the elderly population (Kontis et al., 2017). The number of people reaching the age of 100 is increasing every year in the world (Martin \& Baek, 2018; Rochon et. al., 2014). In previous times, it was not normal for a person to live enough to see his/her grandson's child, but nowadays it is considered as normal.

There are two major consequences of such demographic change for the future. First, health and insurance sectors are under great pressure. Especially for women who have a longer life expectancy than men, but generally have lower education and income levels, health care costs are a critical problem that needs to be addressed and the renovation of an administrative structure is unavoidable. Secondly, and similar to administrative structures, significant changes are also expected in family structures, and even today these changes are remarkable. For example, in a family, the years that three or even four generations can live together are increasing. Improved health quality of life allows grandparents spending more and quality time with their children and grandchildren. On the other hand, the necessity to provide both instrumental and emotional care to the aging member of the family increases as well.

\footnotetext{
* The current study is part of a larger project funded by Turkish Academy of Sciences (TUBITAK, Support Code: 113K537) ** Asst. Prof., Ufuk University, Faculty of Arts and Sciences, Ankara-Turkey, meltem.anafarta @ ufuk.edu.tr, ORCID ID: 00000002-4810-893X

*** Asst. Prof., Ufuk University, Faculty of Arts and Sciences, Ankara-Turkey, funda.kutlu@ufuk.edu.tr, ORCID ID: 00000002-6182-843X
}

To cite this article:

Anafarta-Şendağ, M. \& Kutlu, F. (2019). Adult daughter-mother attachment: Psychometric properties of Turkish version of adult attachment scale. Journal of Measurement and Evaluation in Education and Psychology, 10(4), 451-466. doi: 10.21031/epod.553763 
Previous research shows that the responsibility for providing care for the elderly parent, regardless of Eastern or Western cultures, is predominantly on daughters or daughter in laws' shoulders (Ataca, Kağıtçıbaşı \& Diri, 2005; Finley, 1989; Ingersoll-Dayton, Starrels \& Dowler, 1996; İmamoğlu, 1987; Kagıtçıbaşı, 1985). In the last decade more daughters have left work to take care of their elderly parents (Manuela, Emmanuele \& Cristina, 2016). These findings point to the importance of dwelling on the relationship between an adult daughter and aging mother in various dimensions.

Considering the aging literature up to date, it could be seen that studies mostly focus on the deterioration of physical and psychological health, health care practices, insurance policies, and stress experienced by the caregivers (e.g., Anderson \& Hussey, 2000; Feng, Liu, Guan \& Mor, 2012; Rowland \& Bellizzi, 2014; Shulz \& Sherwood, 2008). In addition to that, sociological studies focus mostly on concepts as intergenerational solidarity, filial obligation and/or piety to investigate the role of culture in support of the elderly members (e.g., Bengtson, Rosenthal \& Burton, 1990; Bengston \& Oyama, 2007; Rossi \& Rossi, 1990). Although the critical importance of all these factors cannot be denied, the researchers (e.g., Bengtson, Giarrusso, Mabry \& Silverstein, 2002; Lowenstein, Katz \& Gur-Yaish, 2007; Schwarz, Trommsdorff, Kim \& Park, 2006) themselves stated that these factors were insufficient to understand the whole picture and implied that quality of dyadic emotional bond had a central role in completing this picture. Yet the literature has provided little about this issue.

Multiple factors, such as a sense of responsibility, filial obligation, necessity, and respect are determinant in the behaviors of an adult daughter in caring for her mother. However, these factors do not strongly relate to the quality and effectiveness of care provided by them and the emotional burden experienced by both parties, those of which are major determinants in both psychological and physical quality of life both for care givers and takers. At this point, the quality of the emotional bond between adult daughter and mother becomes critical and attachment theory has much to offer about this.

Attachment theory is considered to be unique and informative in terms of highlighting the survival value of the attachment bond, explaining the difference between attachment and dependence, and emphasizing the normalcy of lifelong need for attachment. As stated, an independent/autonomous self is established through a functional bond early in life (Sroufe, Fox \& Pancake, 1983) that in turn facilitates the beliefs about dependability of others and so-called secure attachment (Bowlby, 1969).

It is proposed that early attachment relationships shape the capacity to love someone, to care for someone, and ask someone's care when needed (Waters, Kondo-Ikemura, Posada \& Richters, 1991), thus it organizes emotions and behaviors in close relationships throughout life (Ainsworth, 1989; Bowlby, 1979; Waters, Merrick, Treboux, Crowell \& Albersheim, 2000).

Considering its survival value, an attachment bond is stated to be established not only with one figure but is constructed in a hierarchy composed of a finite number of significant others (Bowlby, 1969/1982). Within this dynamic hierarchy, the primary attachment figure changes from parents to friends and partners, from childhood to adulthood (Rosenthal \& Kobak, 2010). However, attachment to the mother (primary caregiver) was proposed to be unique and non-replaceable (Ainsworth, 1989). Unlike fathers, mothers were shown to preserve a place in the attachment hierarchy throughout their children's lives although their primary status might be replaced by the romantic partners (Doherty \& Feeney, 2004; Rosenthal \& Kobak, 2010). Moreover, it was stated that mothers might regain their primary status in the attachment hierarchy during certain developmental milestones of their adult children such as becoming a parent for the first time (Doherty \& Feeney, 2004).

Despite the empirical evidence for the continuous role of the mother as an attachment figure, the literature has little to provide in understanding the dynamics of this continuous emotional bond between adult children and their elderly parents. In that sense, Cicirelli's early works (1983, 1991, 1993, 1995, 2010) provided some valuable insights about the motivation of adult children to provide both instrumental and emotional care for their elderly parents and whether this role reversal could be interpreted as reciprocity of attachment bond for the sake of others or as an attempt for the adult child to protect the attached figure for the sake of himself or herself. Especially when an elderly parent needs health care due to old age, losing an attachment figure becomes a salient and realistic threat for an adult child. In that case, the dynamics of both instrumental and emotional caregiving provided to an elderly 
parent by an adult child might be more complex than it has been known to be. To answer such questions Cicirelli (1991) pointed out the absence of appropriate measurement tool, and thus constructed the Adult Attachment Scale (AAS) that aims to assess the level of an adult child's current attachment to the mother.

The scale has been developed and validated in various studies conducted with adult daughters who were providing instrumental care for their parents (Cicirelli, 1991, 1993, 1995). By utilizing AAS, Cicirelli (1993) has examined the adult daughter's helping behaviors and the subjective burden associated with it. Results have revealed that as a parent's need for help, the daughter's feeling of obligation and feeling of attachment increases, the frequency of helping behavior increases as well. On the other hand, independent of the frequency of helping behavior, it was found that the subjective burden was positively correlated with the feeling of obligation but negatively correlated with feeling of attachment. These findings not only emphasize the critical role of the emotional bond between an adult child and elderly parent but also support that AAS can be a valuable tool in future studies as well.

\section{Purpose of the Study}

As stated above, independent of cultures, the responsibility for providing care for elderly parents was shown to be predominantly on daughters (Ataca et al., 2005; Finley, 1989; Ingersoll-Dayton, et al., 1996; İmamoğlu, 1987; Kağıtçıbaş1, 1985; Zhan \& Montgomery, 2003) yet little is known about the emotional dynamics and process of attachment between them. However, when the aging world population and foreseeable societal and familial changes in the future are taken into consideration, understanding of the dynamics of attachment between daughters and aging parents is becoming more and more critical. At this point, AAS that aims to assess the attachment between adult daughters and aging mothers is providing a valuable starting point and opportunities for future studies. Therefore, the purpose of the present study is to adapt AAS into Turkish and test its psychometric properties and factorial structure with adult daughters.

In addition, Cicirelli's (1995) comments about the sample feature in the original study and his suggestions for future studies in this regard were also taken into consideration in this study. Even though AAS was developed with adult women who regularly provide help for their parents, Cicirelli (1995) emphasized that it is important to test this scale with adult women who do not provide help to their parents for many different reasons (such as living away, workload of daughter, absence of parents need, presence of other children helping mother). Therefore, in the present study, the structure invariance of AAS was examined with two groups of adult daughters who did and did not provide instrumental help to their mothers on a regular base.

\section{METHOD}

The research was conducted with a cross-sectional survey method that aims to examine the existing aspects of participants. The sampling procedure has completed in two stages. At first, the Turkish Statistical Institute enlisted 650 street numbers for each income level (low, average, and high-income levels) which totals to 1950 street numbers among 456 neighborhoods in 7 major municipalities in Ankara by Stratified Random Sampling. Although the neighborhoods were determined by stratified random sampling, the participants in those neighborhoods were selected according to the purpose of the study and their approval. Therefore, the second stage of the sampling procedure was purposive. Accordingly, adult women who were being married and having mothers alive at the time of the study were invited to participate.

\section{Participants}

In total, 560 married women $\left(\bar{X}_{\text {age }}=38.6, S D_{\text {age }}=8.68\right.$, Range: $25-65$ years $)$ whose mothers were alive and did not need care at the time of the study were participants of the study. 
The participants were divided into two groups according to whether they regularly helped their mothers in daily tasks (e.g., cleaning, shopping, arranging doctor appointments, handling bank accounts and payments etc., $)$ in the last 3 months. The first group included 304 women $\left(\bar{X}_{\text {age }}=38.8, S D_{\text {age }}=8.57\right.$, Range: $23-65$ years) labeled as "Daily Help (DH)". The second group included 256 women $\left(\bar{X}_{\text {age }}=38.5\right.$, $S D_{\text {age }}=8.78$, Range: $25-65$ years) and labeled as "No Daily Help (NDH)". In the DH group $60 \%$ ( $n=$ $184)$ of the women had a university degree or more and 65\% $(n=195)$ were employed at the time of the study. Similarly, in the NDH group, 53\% $(n=137)$ of the women had a university degree or more and $56 \%(n=140)$ were employed at the time of the study. Considering the residency status of women in DH Group, $53 \%(n=160)$ were living very close by with their mothers (in the same house, building or neighborhood), $30 \%(n=92)$ were living in the same city but in distant neighborhoods, and $17 \%(n=$ 52) were living in a different city than their mothers. Considering the residency status of women in NDH Group, $29 \%(n=73)$ were living very close by with their mothers, $35 \%(n=90)$ were living in the same city but in distant neighborhoods, and 36\% $(n=92)$ were living in a different city than their mothers.

\section{Data Collection Instruments}

\section{Adult attachment scale (AAS)}

The original scale (Cicirelli, 1991, 1995) consists of 16 items representing the basic aspects of secure attachment as seeking security or comfort (e.g. "At times when I have some trouble or difficulty, my mother's image seems to come to my mind"), distress upon separation (e.g. "If I am unable to see my mother for a long time, it bothers me a lot"), joy upon reunion (e.g. "When I have not seen my mother for a while, I feel happy when I see her again"), and feelings of love and closeness (e.g. "Being with my mother makes me feel very happy"). The factorial structure and psychometric properties of the scale were tested with a sample of adult daughters who were providing care for their elderly mothers at the time of the study and the exploratory factor analysis indicated 2 factors. After the elimination of one item that loaded heavily on both factors (Item 12: "When I have been away from my mother for a long time, I feel a sense of security to be with her again ") considerable overlap between the two factors was observed so the scale was regarded as unidimensional. The significant correlation of AAS with love ( $r$ $=.73)$, trust $(r=.60)$, and interpersonal antagonism $(r=-.28)$ were stated in support of validity. Furthermore, adult daughters' attachment to their mothers assessed by the AAS was stated to be a better predictor of daughters' helping behavior than love, trust, and interpersonal antagonism. Lastly, AAS was reported to have considerable stability assessed by internal consistency reliability $(\alpha=.95)$ and one year test-retest reliability $(r=.73)$.

The final version of the scale consists of 15 items and is rated on a 7-point Likert Scale $(1=$ Totally Disagree and $7=$ Totally Agree). Higher scores are pointing to a stronger level of attachment to the mother.

\section{Mother-adult daughter questionnaire (MAD)}

Originally developed by Rastogi (2002), MAD aims to assess the various aspects of adult daughters' current relationship with their mothers across different cultures. The questionnaire has 18 items rated on a 5-point Likert scale $(1=$ Very False and $5=$ Very True $)$ and 7 single items that are not included in the scale score but providing extra information about the mother-daughter relationship and recommended to be selected following the purpose of the research.

The Turkish version of MAD has shown to have good psychometric qualities (Onayl, Erdur-Baker \& Aksöz, 2010) and composed of 2 factors. The first factor is "Connectedness" (10 items) and represents the mutual ability to share feelings and opinions, as well as to make sacrifices within the context of the adult daughter-mother relationship (e.g. "I can share my intimate secrets with my mother; My mother can share her intimate secrets with me"). The second factor is "Trust in Hierarchy" (8 items) and represents the respect for the mothers' wisdom and her higher status in the family hierarchy; a reported 
positive aspect of an adult-parent relationship in collectivistic cultures (e.g. "I feel I can use my mother's wisdom as a resource when making decisions"). The strong correlation between MAD and parental bonding was established $(r=.69)$ to support validity. Test-retest reliability was satisfactory for 3 weeks interval $(r=.90)$ and internal consistency for the whole scale and two factors were between .88 and .91 . For the present study, internal consistency was found .88 for "Connectedness", .87 for "Trust in Hierarchy", and .91 for the whole scale.

Regarding the purpose of the study, 2 items (among 7 single items of MAD) questioning the feeling of closeness and overall relationship satisfaction with the mother were selected.

\section{WHOTO}

This instrument (Hazan \& Zeifman, 1994) was constructed to investigate individuals' attachment network and the relative primacy of significant others in the attachment hierarchy. In the present study, the revised version of WHOTO (Fraley \& Davis, 1997; Trinke \& Bartholomew, 1997) including 6 items for three attachment functions (proximity seeking, secure base, safe haven) was used. Example items can be listed as; "People you make sure to see or talk to frequently" for physical proximity seeking (PP), "People you immediately think of contacting when something bad happens" for safe haven (SH), and "People you know always wants the best for you" for secure base (SB). For each item, the participants are required to give 4 names in order of significance. The scores are from 4 (the first person listed) to 1 (the last person listed) with higher scores indicating the primacy of the figure. The primacy score for each attachment figure could be obtained both for each function separately and totally by averaging scores across each item.

WHOTO was tested with Turkish married women (Gündoğdu-Aktürk, 2010) and internal consistency for overall attachment primacy was established between .85 and .90 for primary attachment figures (spouse, mother, father, and children). Furthermore, satisfactory correlation between WHOTO and attachment avoidance $(r=-.43)$, marital satisfaction $(r=.40)$, and emotional caregiving style $(r=.40)$ was established to support the validity. For the study, only attachment primacy of mother was calculated for all attachment functions separately.

\section{Personal information form}

In addition to the scale items, the participants' age, level of education, employment status, residency status, frequency of contact with the mother in one week (face to face, phone, email etc.), whether the mother has any age-related health condition that needs care, and whether they provided regular help to their mothers in the daily tasks during the last 3 months were asked.

\section{Procedure}

The present study was approved by the ethical committee of the university where the research was being held. The study was completed as part of a larger project titled "Adult Daughter-Mother Attachment: The Relationship between Caregiving Style of Adult Daughter, Mothers' Psychological Well-Being and Future Care Seeking", granted by Turkish Academy of Sciences between 2014 and 2017.

Before the data collection, AAS (Cicirelli, 1995) was translated into Turkish utilizing translation and back-translation procedure by the researchers who had the command of both languages. Considering the range of SES and education level, the scale was constructed as 5 point Likert Scale $(1=$ Totally Disagree; $5=$ Totally Agree) rather than 7 point as in the original form, in order to control the extreme responses and the high level of skewness and kurtosis (Hui \& Triandis, 1989, Lozano, Garcia-Cueto \& Muniz, 2008).

The data was collected from the psychology undergraduate students. Health centers, mukhtars, pharmacies, shopping malls, parks and other similar public areas in the neighborhoods listed by Turkish 
Statistical Institute were visited and the research was completed with women who met the inclusion criteria of the research and volunteered to participate in the study. After signing the informed consent form, the scales were handed to the participants in an open envelope and asked to fill in that instant. The completed scales were received in a sealed envelope. Applications lasted approximately 15 minutes. In the end, participants were given a gift voucher of 10 Turkish Liras as a token of appreciation and were asked if they are willing to participate for the second time. Women who agreed to participate in the retest were asked for their contact number or email address.

Data collection process had been completed with 600 participants however, 40 of them were discarded due to missing data. The analyses were completed with 560 participants. Six months after the first test, the retest was completed with women $(21 \%, n=120)$ who agreed to participate for the second time.

\section{Data Analysis}

The factor structure of AAS was first tested for DH Group using EFA. Secondly, the factor structure obtained for the DH Group was confirmed for the NDH Group by CFA and the measurement invariance was tested.

The internal consistency of the scale was computed by Cronbach's Alpha coefficient. Also, test-retest reliability was assessed by Pearson correlation coefficients for the 6-month interval. Finally, Pearson's correlation coefficients of AAS with MAD and WHOTO as theoretically and empirically related and similar constructs were tested in support of convergent and concurrent validity.

\section{RESULTS}

Prior to analysis data were screened for missing data and was found to be no more than $5 \%$ of the total number of items. Mean replacement was preferred for interval variables. Univariate and multivariate outliers, normality, and linearity were examined and assured for the data.

\section{Exploratory Factor Analysis for DH Group (EFA)}

Before EFA, inter-item correlations for singularity, VIF (variance inflation factors), CI (condition indices), and TI (Tolerance Indices) for multicollinearity problems were examined for 15 items in the original AAS. For multicollinearity, VIF $>5$, CI $>30$, and TI $<.20$ were accepted as critical levels (James, Witten, Hastie \& Tibshirani, 2014). Accordingly, the item 14 ("When I am with my mom I feel I am with someone whom I can totally depend on") was found to be critical in terms of multicollinearity $(\mathrm{VIF}=4.75, \mathrm{CI}=36.46, \mathrm{TI}=.21)$. This item also was found to have a high level of inter-item correlation ( $r=.85$ ) with item 9 ("When I am with my mom I feel I am with someone I can lean on"). When examined closely, it was noted that there was a subtle difference between the expressions of these two items in English, which might be lost in translation. Since multicollinearity statistics for item 9 were satisfactory, item 14 was decided to be discarded from further analyses.

After the elimination of one item from the original scale, the factorability of 14 AAS items for DH Group ( $\mathrm{N}=304)$ was examined. The Kaiser-Meyer-Olkin measure verified the sampling adequacy for the analysis, KMO = .95 (Field, 2013; Tabachnick \& Fidell, 2013). The result of the Barlett test of sphericity $\left(\chi^{2}=3706.1 p<.001\right)$ were ensured that the data was appropriate for factor analysis. EFA was conducted initially regarding the 4-factor structure implied in the original study. However, it was found that the last two factors had eigenvalues less than Kaiser's criterion of 1 and the distribution of items was not conceptually and theoretically meaningful. Therefore, the research assumption about twofactor structure of the scale was tested.

A principal component analysis (PCA) was conducted to determine the factor structure. Based on the eigenvalues and the scree plot, a two-factor solution was indicated. Item 6 has been eliminated due to cross-loading, considering the loadings were above .30 for both factors (Tabachnick \& Fidell, 2013). After the elimination of Item 6, interpretation of the two factors was conducted by Direct Oblimin 
rotation since the factors were conceptually related. Results showed that the variance explained by the first and second factor were $64.32 \%$ and $7.53 \%$ respectively, making $71.86 \%$ of total variance explained by 13 items of AAS. The factor loadings of the items are presented in Table 1.

Table 1. Factor Loadings, Mean and Standard Deviation for AAS

\begin{tabular}{lrrrr}
\hline & Factor I & Factor II & & \\
\hline & Secure Base & Safe Haven & $\boldsymbol{M}$ & SD \\
\hline Item 4 & .99 & -.16 & 4.07 & .83 \\
Item 9 & .87 & .00 & 3.94 & 1.00 \\
Item 7 & .87 & .04 & 3.93 & .94 \\
Item 15 & .82 & .10 & 3.92 & .93 \\
Item 11 & .79 & -.01 & 3.94 & .88 \\
Item 1 & .77 & .08 & 3.88 & .99 \\
Item 3 & .75 & .10 & 4.07 & .89 \\
Item 6 & .48 & .37 & 3.62 & 1.09 \\
Item 10 & -.08 & .95 & 3.33 & 1.23 \\
Item 5 & -.02 & .89 & 3.00 & 1.34 \\
Item 8 & -.05 & .87 & 3.07 & 1.27 \\
Item 13 & .18 & .74 & 3.31 & 1.23 \\
Item 2 & .13 & .66 & 3.26 \\
Item 16 & .06 & .66 & 3.29 & 1.15 \\
\hline Eigenvalues & 9.00 & 1.10 & & 1.34 \\
Exp. Variance & 64.32 & 7.53 & \\
\hline
\end{tabular}

When the distribution of items was examined, Factor 1 was seen to include items that represent the internalized aspect of attachment of which the mother was perceived as a sense of security even without the presence of active threat; therefore labelled as "Secure Base" (SB) (e.g. "When I am with my mother, I feel that I am with someone I can depend on"). Furthermore, Factor 2 was labeled as "Safe Haven" (SH) considering the items loaded on this factor were about the actual support seeking in the presence of threat (e.g. "If I am in trouble, the first person I want to talk to is my mother").

\section{Confirmatory Factor Analysis for NDH Group (CFA)}

Similar to the original study (Cicirelli, 1995), the EFA was conducted with adult women who provided instrumental help to their mothers in the last 3 months (DH Group). Additionally, and as suggested, the factor structure obtained by EFA was confirmed in the second group of adult women that was similar to the first group in terms of age, education level, and occupational status, but different in terms of daily help provided to the mothers. The second group (NDH) was composed of adult women who did not provide instrumental help to their mothers in the last 3 months for several different reasons (such as living away, the workload of a daughter, absence of parents need, presence of other children helping mother). The purpose of conducting CFA for the NDH group is to confirm the similar factor structure established by EFA in the DH Group and to establish measurement invariance.

Before CFA, inter-item correlations for singularity, VIF, CI, and TI for multicollinearity problems were examined and assured for the NDH Group.

CFA for NDH Group $(N=256)$ was conducted as a higher order construct of adult attachment composed of two factors as SB (7 items) and SH (6 items) established by EFA for DH Group. The model indices of 13 items were as follows: $\chi^{2}(64)=215.52 p<.01, \chi^{2} / \mathrm{sd}=3.37$, GFI $=.88$, AGFI $=.84$, CFI $=.94$, $\mathrm{TLI}=.93$, RMSEA $=.09$, suggesting a poor fit. Hence, the regression weights and modification indices pointed out that the fit of the model could be improved. Considering the modification indices, the error term of the item 4 was correlated with items 7 and 3 within the AAS-SB factor. Also, the error terms of items 10 and 13, 8 and 16 in the AAS-SH factor were correlated. As a result, the second model presented an adequate fit for 13 items with two factors $\left(\chi^{2}(59)=232.92, p<.01, \chi^{2} / \mathrm{sd}=3.9\right.$, GFI $=.94$, AGFI $=$ $.90, \mathrm{CFI}=.96, \mathrm{TLI}=.95, \mathrm{RMSEA}=.07)$. As shown in Figure 1 , weights for the regressions of item scores on their respective factors were between .56 and .88 . 


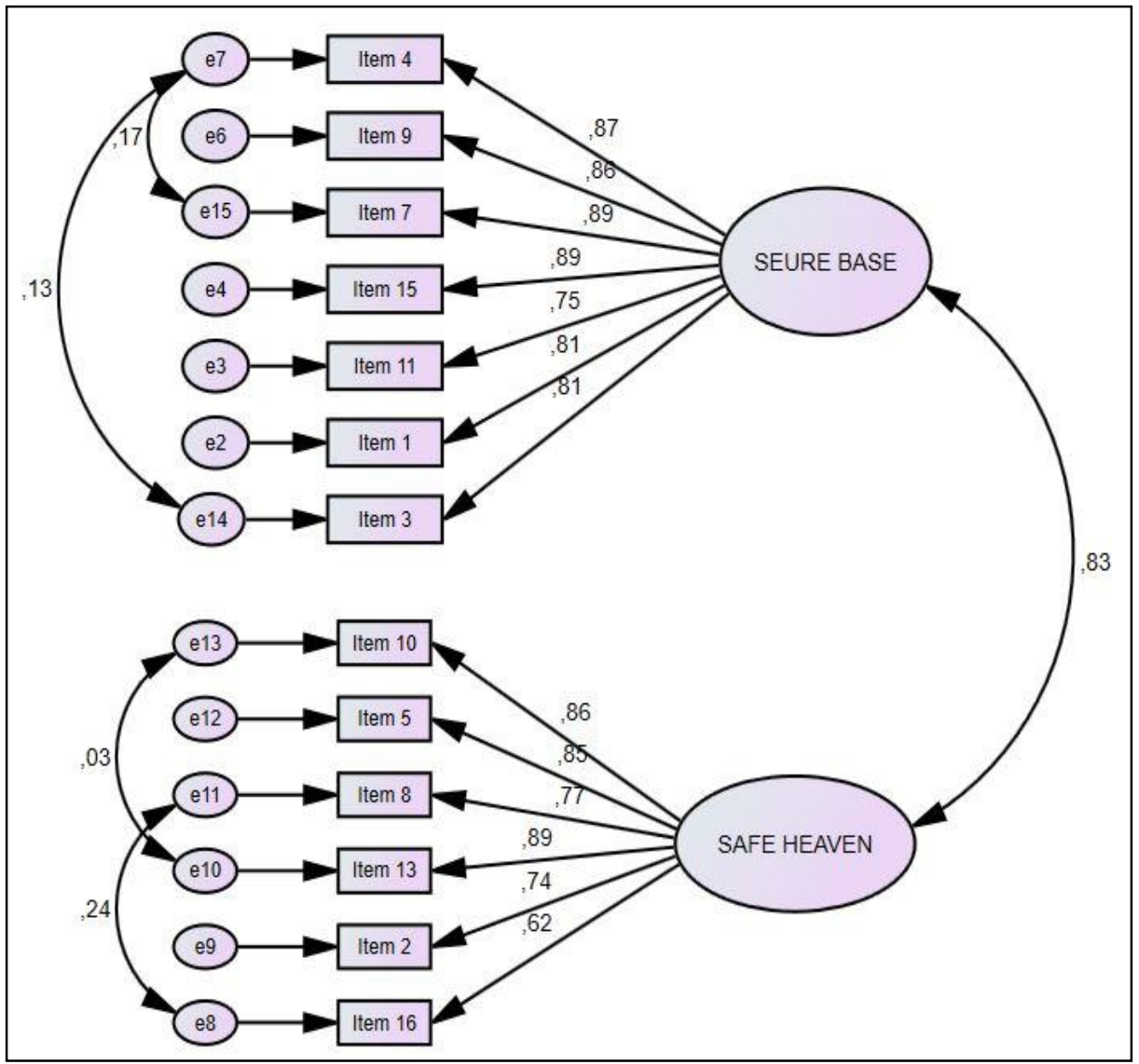

Figure 1. General Measurement Model for NDH Group

\section{Measurement Invariance for DH and NDH Group}

Based on the acceptable results of CFA for NDH Group $\left(\chi^{2}(59)=232.92, p<.01, \chi^{2} / \mathrm{sd}=3.9\right.$, GFI $=$ .94$, AGFI $=.90$, CFI $=.96$, TLI $=.95$, RMSEA $=.07)$ multi-group analysis was conducted for measurement invariance. At first, the CFA for DH Group was established as well for comparison $\left(\chi^{2}(60)\right.$ $\left.=172.95, p<.01, \chi^{2} / \mathrm{sd}=2.88, \mathrm{GFI}=.92, \mathrm{AGFI}=.86, \mathrm{CFI}=.97, \mathrm{TLI}=.96, \mathrm{RMSEA}=.07\right)$. The configural model yielded an adequate fit to the data as seen in Table 2.

Table 2. The Goodness of Fit Indices for Invariance Test and Results of $\chi^{2}$ Difference Tests

\begin{tabular}{|c|c|c|c|c|c|c|c|c|}
\hline & $\chi^{2}$ & $d f$ & $\Delta \chi^{2}$ & $(\triangle d f)$ & RMSEA & $\begin{array}{l}\text { SRMR } \\
\end{array}$ & CFI & $\triangle \mathrm{CFI}$ \\
\hline $\mathrm{CI}$ & 332.14 & 120 & - & - & .05 & .04 & .965 & - \\
\hline MI & 339.76 & 131 & 7.62 & 11 & .05 & .05 & .965 & .000 \\
\hline FVI & 344.01 & 134 & 11.89 & 14 & .05 & .06 & .965 & .000 \\
\hline FCI & 395.97 & 151 & 63.83 & 31 & .05 & .06 & .959 & .006 \\
\hline
\end{tabular}

Note 1. DH Group $N=304$; NDH Group $N=256$.

Note $2 . \mathrm{CI}=$ configural invariance; $\mathrm{MI}=$ measurement invariance; $\mathrm{FVI}=$ factor variance invariance; $\mathrm{FCI}=$ factor covariance invariance.

Comparing the MI, FVI, and FCI models with the CI model, the changes in $\chi^{2}$ were nonsignificant. Further, the changes in CFI between CI and MI, between MI and FVI, and between FVI and FCI were either smaller than or equal to .01. These findings of invariance testing provided support for factorial invariance of the AAS scale across two groups. 


\section{Reliability: Internal Consistency and Test-Retest Reliability}

The final version AAS is composed of 13 items with Cronbach's Alfa coefficient of .95 for the total scale, .94 for the AAS-SB, and .89 for the AAS-SH. Item-total correlations ranged between .63 and .82 for AAS-SB and .42 and .73 for AAS-SH. Also, the correlation coefficients of AAS-SB and AAS-SH with total scale were .93 and .96 respectively. The correlation coefficient between the two factors was .78 .

Stability of AAS was tested over the 6-month interval for the $21.4 \%$ of the participants $(n=120)$ and the significant correlation coefficient between time 1 and time 2 was established for AAS-SB $(r=.75)$, AAS-SH $(r=.69)$, and for the total scale score $(r=.78)$.

\section{Further Support for AAS: Convergent and Concurrent Validity}

To provide further support for the validity of AAS, correlation coefficients with theoretically and empirically related variables were computed. As presented in Table 3, the AAS scores were found to be weakly and negatively correlated with age (AAS total $r=-.14$, AAS-SB $r=-.10$, ASS-SH $r=-.17$ ), moderately and positively correlated with the frequency of contact with the mother (AAS total $r=.40$, AAS-SB $r=.37$, ASS-SH $r=.38$ ). Furthermore, AAS scores were found to be significantly and strongly correlated with MAD assessing the quality of the current relationship between mother and adult daughters in 4 subdomains, the correlation coefficients were ranging from .54 to .74 .

Lastly, in support of the concurrent validity, AAS was found to be significantly correlated with WHOTO which assesses the primacy of the mother in the attachment hierarchy both in general and separately for each basic function of attachment (Physical Proximity, Secure Base, and Safe Haven). Although generally and consistently significant, the correlation coefficient of AAS-SB with WHOTO-SB $(r=.45)$ were relatively stronger than WHOTO-SH $(r=.35)$ and WHOTO-PP $(r=.33)$. Also, the correlation coefficient of AAS-SH with WHOTO-SH $(r=.54)$ and WHOTO-PP $(r=.56)$ were relatively stronger than WHOTO-SB $(r=.35)$ implicating the differential pattern of relationship for the 2 factors of AAS.

Table 3. Pearson Correlation Coefficients of AAS with Related and Similar Constructs

\begin{tabular}{lrrr}
\hline & AAS-SB & AAS-SH & AAS-TOT \\
\hline Age & $-.10^{*}$ & $-.17^{* *}$ & $-.14^{* * *}$ \\
Frequency of Contact & $.37^{* *}$ & $.38^{* *}$ & $.40^{* *}$ \\
\hline MAD-Connectedness & $.70^{* *}$ & $.69^{* *}$ & $.74^{* * *}$ \\
MAD-Hierarchy Trust & $.48^{* *}$ & $.66^{* *}$ & $.62^{* *}$ \\
MAD-Feeling of Closeness & $.55^{* *}$ & $.58^{* *}$ & $.60^{* *}$ \\
MAD-Rlt. Satisfaction & $.54^{* *}$ & $.55^{* *}$ & $.58^{* *}$ \\
WHOTO-SB & $.45^{* *}$ & $.35^{* *}$ & $.42^{* *}$ \\
WHOTO-SH & $.35^{* *}$ & $.54^{* *}$ & $.50^{* *}$ \\
WHOTO-PP & $.33^{* *}$ & $.56^{* *}$ & $.51^{* *}$ \\
\hline
\end{tabular}

Note 1. MAD=Mother-Adult Daughter Questionnaire, WHOTO-PP = Physical Proximity, WHOTO-SB = Secure Base, WHOTO-SH= Safe Haven, WHOTO-TOT $=$ Total.

${ }^{*} p<.05,{ }^{* *} p<.01$

\section{DISCUSSION and CONCLUSION}

In this study, the Turkish validity and reliability of AAS which was specifically developed for the purpose of assessing adult daughters' attachment to their aging mothers, was tested.

When the structural analyses were considered, results were consistent with the original study, and beyond that, a more coherent picture was provided in support of the construct validity. Although AAS was originally developed depending on the four basic aspects of secure attachment (seeking security or comfort, distress upon separation, joy upon reunion, and feelings of love and closeness), the result of the factor analysis was reported to be unexpected and inconclusive. Thus, AAS has been tentatively regarded as a unidimensional construct. By pointing out the small size and homogeneous structure of 
the sample in the original study, Cicirelli (1995) had stated that the construct validity of AAS should be tested in a larger and heterogeneous sample. More specifically, Cicirelli (1995) emphasized the importance of replication with a group of adults who could not help their parents for any reason, recalling that AAS was only developed with adult daughters who regularly helped their mothers on daily tasks. Regarding this, the present study was designed with a relatively larger sample size that was separated into two groups as adult daughters who did and did not provide regular help to their mothers on daily tasks.

First, EFA was conducted with a sample of adult women, who had similar characteristics to the sample of the original study in terms of the instrumental help provided regularly to mothers (DH Group). Depending on the preliminary results, two items were discarded from the Turkish version of the scale either due to multicollinearity or high cross-loading. After discarding the 2 items, the two-factor solution and the distribution of items were found to be similar to the original study only with some minor differences that made the interpretation conceptually more meaningful. When the content of the factors examined closely, rather than four-factor structure proposed by Cicirelli (1995) an alternative and theoretically more meaningful perspective for labeling the factors popped out. Accordingly, factors were labeled as "Secure Base" and "Safe Haven"; two basic functions of attachment one of which represents the source of security without the presence of active support seeking and the other one of which represents the actual seek of support in the presence of a threat. This factor structure established by EFA was further validated by CFA with the second group of adult daughters who were not providing instrumental help to their mothers regularly (NDH Group). The results revealed that the factor structure obtained was valid for both samples. Furthermore; measurement, factor variance, and factor covariance invariance were demonstrated for two samples by multi-group analysis and the results were considered as strong support for the structural validity of AAS.

Concurrent validity of AAS was tested by examining its correlation with WHOTO a scale of which, assesses attachment network and the relative primacy of significant others in the attachment hierarchy. AAS and WHOTO are similar not only conceptually but also structurally. However, the major difference between these two scales is that WHOTO requires an evaluation of the relative importance of the many significant others in one's life. Because of that, WHOTO is sensitive to the width of attachment network and the scale score might vary according to marital status, death of a family member, number of siblings, children, friends, and relatives, etc., which might complicate the interpretation of scale score. In contrast, AAS requires a relationship-specific evaluation independent of the presence of other attachment figures. In favor of concurrent validity, results presented that AAS, in general, is positively correlated with WHOTO. This means that as adult daughters' level of attachment to mother increases, the mothers' priority in the attachment hierarchy increases compared to other attachment figures. Besides, it was noted that similar dimensions (e.g. AAS-SB \& WHITE-SB) on both scales were more strongly related to each other than non-similar dimensions (e.g. AAS-SB \& WHOTO-SH). Although the statistical significance of these differences in correlation coefficients has not been tested, such a pattern could be considered as remarkable.

Convergent validity of AAS was tested by examining its correlation with theoretically related concepts such as general relationship quality assessed by MAD and frequency of contact. As expected, AAS was found to be strongly correlated with all MAD subscales and moderately correlated with the frequency of contact. Although weak, significant negative correlation between AAS and the age of adult daughter also has been found. This finding is consistent with the attachment theory which states that the importance of the mother as attachment figure decreases in time and that attachment is transferred to friends, romantic partners, and spouses over time (Rosenthal \& Kobak, 2010). This result should also be considered as critical in pointing out the appropriate way of interpretation of the scale score. Accordingly, it should be noted that attachment level which is sensitive to developmental changes in the attachment network, is not necessarily accounted as the attachment security that is resistant to change. Thus, for future research, it is strongly advised that AAS is used and interpreted in its conceptual limits.

To sum up, the Turkish version of AAS could be accepted as a reliable and valid measure of the level of adult daughters' current attachment to their mothers. AAS-Turkish is composed of two conceptually related factors that can be utilized both as separate scores to point out the significance of mother either 
as a secure base or haven and as a total score pointing out the significance of mother as an attachment figure. The scale should be fruitful for researchers in testing certain predictions and understanding the dynamics of attachment bond between adult children and their elderly parents. Given that the global population is rapidly aging (He et al., 2016), that the cultural expectations for adult daughters as being primary caregivers for the elderly are increasing (Ataca et al., 2005; Finley, 1989; Ingersoll-Dayton et.al., 1996; İmamoğlu, 1987; Kağıtçıbaş1, 1985; Zahn \& Montgomery, 2003), and that attachment theory still offers little to understand the dynamics of attachment relationships in late life AAS could be a valuable tool in providing preliminary answers.

\section{REFERENCES}

Ainsworth, M. D. S. (1989). Attachment beyond infancy. American Psychologist, 44(4), 709-716. Retrieved from https://pdfs.semanticscholar.org/ 5431/41e657bda74736ff87ac10d70643cd639892.pdf

Anderson, G. F., \& Hussey, P.S. (2000). Population aging: A comparison among industrialized countries populations around the world are growing older, but the trends are not cause for despair. Health Affairs, (19)3, 191-203. Retrieved from http://hcim.di.fc.ul.pt/hcimwiki/images/3/3a/Anderson2000PopulationAging.pdf.

Ataca, B., Kağıtçıbaşı, Ç., \& Diri, A. (2005). The Turkish family and the value of children: Trends over time. In G. Trommsdorff, \& B. Nauck (Eds.), The value of children in cross-cultural perspective: Case studies from eight societies (pp. 91-119). Lengerich, Germany: Pabst Science.

Bengston, V. L., \& Oyama, P. S. (2007). Intergenerational solidarity and conflict: Strengthening economic and social ties. Department of Economic and Social Affairs Division for Social Policy and Development. Retrieved from https://www.un.org/esa/socdev/unyin/documents/egm_unhq_oct07_bengtson.pdf.

Bengtson, V. L., Rosenthal, C. J., \& Burton, L. M. (1990). Families and aging: Diversity and heterogeneity. In R. Binstock, \& L. George (Eds.), Handbook of Aging and the Social Sciences (pp. 263-287). New York, NY: Academic.

Bengtson, V., Giarrusso, R., Mabry, J. B., \& Silverstein, M. (2002). Solidarity, conflict, and ambivalence: complementary or competing perspectives on intergenerational relationships? Journal of Marriage and Family, 64(3), 568-576 doi: 10.1111/j.1741-3737.2002.00568.x

Bloom, D. E., Canning, D., \& Lubet, A. (2015). Global population aging: Facts, challenges, solutions \& perspectives. Daedalus, 144(2), 80-92. doi:10.1162/daed_a_00332

Bowlby, J. (1969/1982). Attachment and loss: Vol 1: Attachment. New York, NY: Basic Books.

Bowlby, J. (1979). The making and breaking of affectional bonds. London: Tavistock.

Cicirelli, V. G. (1983). Adult children's attachment and helping behavior to elderly parents: A path model. Journal of Marriage and the Family, 45(4), 815-825. Retrieved from https://www.jstor.org/stable/351794

Cicirelli, V. G. (1993). Attachment and obligation as daughters' motives for caregiving behavior and subsequent effect on subjective burden. Psychology and Aging, 8(2), 144-155. doi: 10.1037/0882-7974.8.2.144

Cicirelli, V. G. (1995). A measure of caregiving daughters' attachment to elderly parents. Journal of Family Psychology, 9(1), 89-94. doi: 10.1037/0893-3200.9.1.89

Cicirelli, V. G. (2010). Attachment relationships in old age. Journal of Social and Personal Relationships, 27(2), 191-199. doi: 10.1177/0265407509360984

Cicirelli, VG. (1991). Family caregiving: Autonomous and paternalistic decision making. Newbury Park, CA: Sage.

Doherty, N. A., \& Feeney, J. A. (2004). The composition of attachment networks throughout the adult years. Personal Relationships, 11(4), 469-488. doi: 10.1111/j.1475-6811.2004.00093.x

Field, A. (2013). Discovering statistics using IBM SPSS statistics: And sex and drugs and rock " $n$ " roll, (4th ed.). London: Sage.

Finley, N. J. (1989). Theories of family labor as applied to gender differences in caregiving for elderly. Parents Journal of Marriage and Family, 51(1), 79-86. Retrieved from https://www.jstor.org/stable/352370?seq=1\&cid=pdf-reference\#references_tab_contents

Fraley, R. C., \& Davis, K. E. (1997). Attachment formation and transfer in young adults' close friendships and romantic relationships. Personal Relationships, 4(2), 131-144. doi: 10.1111/j.1475-6811.1997.tb00135.x

Gündoğdu-Aktürk, E. (2010). Attachment figure transference, caregiving styles and marital satisfaction in arranged and love marriages (Unpublished master's thesis). Middle East Technical University, Ankara Retrieved from https://toad.halileksi.net/sites/default/files/pdf/yakin-iliskilerde-bakim-verme-olcegitoad.pdf 
Hazan, C., \& Zeifman, D. (1994). Sex and the psychological tether. In K. Bartholomew \& D. Perlman (Eds.), Advances in personal relationships, Vol. 5: Attachment processes in adulthood (pp. 151-177). London: Jessica Kingsley.

He, W., Goodkind, D., \& Kowal, P. R. (2016). An aging world: 2015. Washington, DC: United States Census Bureau.

Hu, L., \& Bentler, P. M. (1999). Cutoff criteria for fit indexes in covariance structure analysis: Conventionalcriteria versus new alternatives. Structural Equation Modeling: A Multidisciplinary Journal, 6(1), 1-55. doi: $10.1080 / 10705519909540118$

Hui, C. H., \& Triandis, H. C. (1989). Effects of culture and response format on extreme response style. Journal of Cross-Cultural Psychology, 20(3), 296-309. doi: 10.1177/0022022189203004

İmamoğlu, E. O. (1987). An interdependence model of human development. In Ç. Kağıtçıbaşı (Ed), Growth and progress in cross-cultural psychology (pp.138-145). Lisse, Netherlands: Swets \& Zeitlinger.

Ingersoll-Dayton. B, Starrels, M. E., \& Dowler, D. (1996). Caregiving for parents and parents-in-law: Is gender important. The Gerontologist, 36(4), 483-491. doi: 10.1093/geront/36.4.483

James, G., Witten, D., Hastie, T., \& Tibshirani, R. (2014). An introduction to statistical learning: With applications in $R$ (pp. 59-120). New York, NY: Springer.

Kağıtçıbaşı, Ç. (1985). Intra-family interaction and a model of change. In T. Erder (Ed.), Family in Turkish society (pp. 149-166). Ankara: Turkish Social Science Association.

Kontis, V., Bennett, J. E., Mathers, C. D., Li, G., Foreman, K., \& Ezzati, M. (2017). Future life expectancy in 35 industrialised countries: Projections with a Bayesian model ensemble. The Lancet, 389(10076), 13231335. doi: 10.1016/S0140-6736(16)32381-9

Lowenstein, A. (2005). Global ageing and challenges to families. In M. Johnson (Ed.), The Cambridge handbook of age and ageing (pp. 403-412). Cambridge: Cambridge University. doi:10.1017/CBO9780511610714.042

Lowenstein, A., Katz, R., \& Gur-Yaish, N. (2007). Reciprocity in parent-child exchange and life satisfaction among the elderly: A cross-national perspective. Journal of Social Issues, 63(4), 865-883. doi:10.1111/j.1540-4560.2007.00541.X

Lozano, L. M., García-Cueto, E., \& Muñiz, J. (2008). Effect of the number of response categories on the reliability and validity of rating scales. Methodology, 4(2), 73-79. doi: 10.1027/1614-2241.4.2.73

Manuela, N., Emmanuele, P., \& Cristina, S. (2016). Female employment and elderly care: the role of care policies and culture in 21 European countries. Work Employment and Society, 30, 607-630. Retrieved from https://iris.unito.it/retrieve/handle/2318/1559499/132926/Naldini\%20et\%20al_Elderly\%20care_WES_2 016.pdf

Martin, P., \& Baek, Y. (2018). Centenarian in the SAGE encyclopedia of lifespan human development. Thousand Oaks, CA: SAGE Publications, Inc. doi: 10.4135/ 9781506307633.n126.

Onaylı, S., Erdur-Baker, Ö., \& Aksöz, A. (2010). The Turkish adaptation of the mother-adult daughter questionnaire. Procedia-Social and Behavioral Sciences, 5, 1516-1520. doi: 10.1016/j.sbspro.2010.07.318

Rastogi, M. (2002). The mother-adult daughter questionnaire (MAD): Developing a culturally sensitive instrument. The Family Journals, 10(2), 145-155. doi: 10.1177/1066480702102004

Rochon, P. A., Gruneir, A., Wu, W., Gill, S. S., Bronskill, S. E., Seitz, D. P., ..\&\& Anderson, G. M. (2014). Demographic characteristics and healthcare use of centenarians: A population-based cohort study. Journal of the American Geriatrics Society, 62(1), 86-93. doi:10.1111/jgs.12613

Rosenthal, N. L., \& Kobak, R. (2010). Assessing adolescents' attachment hierarchies: Differences across developmental periods and associations with individual adaptation. Journal of Research on Adolescence, 20(3), 678-706. doi: 10.1111/j.1532-7795.2010.00655.x

Rowland, J. H., \& Bellizzi, K. M. (2014). Cancer survivorship issues: Life after treatment and implications for an aging population. Journal of Clinical Oncology, 32(24), 2662-2668. doi:10.1200/jco.2014.55.8361

Sroufe, L. A., Fox, N. E., \& Pancake, V. R. (1983). Attachment and dependency in developmental perspective. Child Development, 54(6), 1615-1627. Retrieved from https://www.jstor.org/stable/1129825

Tabachnick, B. G., \& Fidell, L. S. (2013). Using multivariate statistics (6th. Ed.). Boston, MA: Pearson.

Trinke, S. J., \& Bartholomew, K. (1997). Hierarchies of attachment relationships in young adulthood. Journal of Social and Personal Relationships, 14(5), 603-625. doi: 10.1177/0265407597145002

Trommsdorff, G., \& Nauck, B. (2006) Demographic changes and parent-child relationships. Parenting, 6(4), 343360. doi: 10.1207/s15327922par0604_4

Waters, E., Kondo-Ikemura, K., Posada, G., \& Richters, J. E. (1991). Learning to love: Mechanisms and milestones. In M. Gunner \& L.A. Sroufe (Eds.), Self process in development. The Minnesota Symposia on Child Psychology, Vol. 23. Hillsdale, NJ: Erlbaum. 
Waters, E., Merrick, S., Treboux, D., Crowell, J., \& Albersheim, L. (2000). Attachment security in infancy and early adulthood: A twenty- year longitudinal study. Child Development, 71(3), 684-689. doi:10.1111/1467-8624.00176

\section{Yetişkin Kız - Anne Bağlanması: Yetişkin Bağlanma Skalası Türkçe Versiyonunun Psikometrik Özellikleri}

\section{Giriş}

Dünya nüfusu gittikçe artan bir hızda yaşlanmaktadır (Bloom, Canning \& Lubet, 2015; Lowenstein, 2005; Trommsdorff \& Nauck, 2006). Gelecek 30 yıl içerisinde Avrupa nüfusunun \%28'nin 65 yaş üstü olacağına işaret edilmektedir (He, Goodkind \& Kowall, 2016). Gün geçtikçe hızlanan bu değişimin sağlık sektörü için taşıdığı risklerle birlikte, sosyal yaşantı ve aile yapısında, bugünden gözlemlenmeye başlayan, olumlu ve olumsuz sonuçları da tahmin edilmektedir. Buna göre; bir ailede üç ve hatta dört neslin bir arada geçireceği yıllar artmakta, artan sağlık yaşam kalitesi büyük ebeveynlerin aile dinamiklerindeki rol ve sorumluluklarını farklılaştırmaktadır. Öte yandan, yaşlanan ve bakıma ihtiyaç duyan aile üyelerine bakım sorumluluğu ve süresi de artmaktadır. Birçok farklı kültürde, yaşlanan aile üyesine bakım verme sorumluluğunun kız çocuğunda olduğu (Ataca, Kağıtçıbaş1, \& Diri, 2005; İmamoğlu, 1987; Ingersoll-Dayton, Starrels, \& Dowler, 1996; Zhan \& Montgomery, 2003) ve son yıllarda daha fazla kadının yaşlı ebeveynine bakım vermek için işten ayrıldığı rapor edilmektedir (Manuela, Emmanuele, \& Cristina, 2016).

Bu değişimlerin işaret ettiği riskler ve çözüm ihtiyacı ile paralel olarak alan yazındaki araştırmaların arttığı, psikobiyolojik boyutta yaşı sağlığı, yaşlı bakım uygulamaları, bakım veren yükü ve stresi (örn., Feng, Liu, Guan \& Mor, 2012; Rowland \& Bellizzi, 2014), sosyolojik boyutta ise nesiller aras1 dayanışma ve evlat yükümlülüğü (örn., Bengtson, Rosenthal \& Burton, 1990; Bengston \& Oyama, 2007) gibi konuların ağırlıklı olarak vurgulandığı dikkat çekmektedir. Bu konuların önemi yadsınamaz olmakla birlikte, bazı araştırmacılar (örn., Bengtson, Giarrusso, Mabry \& Silverstein, 2002; Lowenstein, Katz \& Gur-Yaish, 2007; Schwarz, Trommsdorff, Kim \& Park, 2006) büyük resimdeki önemli bir boşluğa işaret etmekte; bakım alan ve veren arasındaki duygusal bağın göz ardı edildiğine vurgu yapmaktadır. Yaşlanan aile bireyine bakım vermede her ne kadar sorumluluk duygusu, evlat yükümlülüğü, zorunluluk, gereklilik ve saygı gibi faktörler belirleyici olsa da, bu faktörlerin sunulan bakımın kalitesi ve etkinliği ile ilişkili olmadığı, her iki tarafın deneyimlediği duygusal stres, fiziksel ve psikolojik yaşam kalitesinde de temel etken olmadığı görülmektedir. Bu noktada, yetişkin çocuğun yaşlı ebeveyni ile kurduğu duygusal bağ kalitesinin kritik bir öneme sahip olduğu ifade edilmekte ve bağlanma kuramına işaret edilmektedir (örn., Bengtson, Giarrusso, Mabry \& Silverstein, 2002; Lowenstein, Katz \& Gur-Yaish, 2007).

Bağlanma kuramı, bağlanmanın yaşamsal önemini vurgulaması ve ömür boyu bağ kurma ihtiyacının normalliğine işaret etmesi açısından özgün ve etkili bir yaklaşım ortaya koymaktadır. Yaşamın en erken döneminde, ilk olarak çoğunlukla anneyle kurulan güvenli bağın sevme, önemseme, umursama, yardım etme ve yardım isteme potansiyelini şekillendirdiği (Waters, Kondo-Ikemura, Posada, \& Richters, 1991) dolayısıyla, yaşam boyu tüm yakın ilişkilerdeki duygu ve davranışların düzenlenmesinde kritik bir faktör olduğu belirtilmektedir (Ainsworth, 1989; Bowlby, 1979; Waters, Merrick, Treboux, Crowell, \& Albersheim, 2000).

Yalnızca tek bir kişiyle kurulmayan bağlanmanın, sınırlı sayıda önemli diğerlerinden oluşan hiyerarşik bir ağ olduğu (Bowlby,1969/1982), bu ağın gelişimsel süreçte değiştiği ve birincil bağlanma figürünün zamanla ebeveynden arkadaşa, arkadaştan eşe transfer edildiği ifade edilmektedir (Rosenthal \& Kobak, 2010). Ancak babanın aksine, annenin statüsü değişse de her zaman bağlanma ağında yeri olduğu ve hatta yaşamdaki gelişimsel dönüm noktalarında (ilk kez anne/baba olmak gibi) annenin hiyerarşideki birincil pozisyona tekrar yükselebildiği belirtilmektedir (Doherty \& Feeney, 2004; Rosenthal \& Kobak, 2010). Bir bağlanma figürü olarak annenin yaşam boyu devam eden rolü ampirik olarak desteklenmiş 
olsa da yetişkin çocuk ve ebeveyni arasındaki duygusal bağın dinamikleri üzerine alan yazında oldukça sınırlı sayıda çalışma bulunmaktadır. Bu noktada Cicirelli'nin araştırmaları (1983, 1991, 1993, 1995, 2010), yetişkin çocukların yaşlı ebeveynlerine hem duygusal anlamda ilgi göstermeleri hem de gündelik işler açısından yardımcı olmalarındaki motivasyonun anlaşılmasında bir başlangıç olmuştur. Alan yazındaki boşluğa ve yetişkin çocuğun anneyle devam eden bağlanmasının değerlendirilmesinde uygun bir aracın yokluğuna vurgu yapan Cicirelli (1991), bu amaçla Yetişkin Bağlanma Skalası'nı (YBS) geliştirmiştir.

YBS, gündelik işlerde annelerine düzenli olarak yardım eden kadınlarla geliştirilmiş ve farklı araştırmalarda amaca yönelik test edilmiştir (Cicirelli, 1991, 1993, 1995). Buna göre; yetişkin kızların yardım sıklığı ile algıladıkları bakım verme yükü arasındaki ilişkiyi inceleyen Cicirelli (1993), öncelikle yardım sıklığının ebeveynin yardıma ihtiyaç duyması, yetişkin kızın yükümlülük hissi ve bağlanma düzeyi ile ilişkili olduğunu belirtmiştir. Ancak, yardım sıklı̆̆ından bağımsız olarak algılanan bakım verme yükünün hissedilen yükümlülük ile pozitif, bağlanma düzeyiyle ise negatif yönde ilişkili olduğunu ortaya koymuştur. Alan yazındaki bu ilk çalışmalar, bir yandan yetişkin çocuk - anne arasındaki duygusal bağın anlaşılmasının kritik önemine bir yandan da YBS' nin ilerideki araştırmalarda değerli bir araç olarak kullanılabileceğine işaret etmektedir.

Türk kültüründe, yaşlanan ebeveyne bakım verme yükümlülüğünün ağılıklı olarak kız çocuğunda olması (Ataca, Kağıtçıbaşı, \& Diri, 2005; İmamoğlu, 1987), bakım verme sürecinde karşılıklı kurulan duygusal bağın önemi yadsınamaz olmakla birlikte araştırmacılar tarafından konunun göz ardı edilmiş olması, yetişkin çocuk - anne bağlanması üzerine ulusal ve uluslararası alan yazında sınırlı sayıda bilgiye ulaşı1ması nedeniyle ve konuyla ilgili araştırmalara bir başlangıç noktası olması amacıyla, bu çalışmada YBS' nin Türkçe 'ye uyarlaması hedeflenmiştir.

\section{Yöntem}

Araştırmaya, yaşları 25-65 arasında değişen, evli ve anneleri halen hayatta olan yetişkin kadınlar katılmıştır. Katılımcılar, son 3 ayda gündelik işlerde (örn., temizlik, alışveriş, banka işleri, sağlık işlerinin takibi vb.) annelerine düzenli yardım etme durumuna göre iki gruba ayrılmışıtır. Düzenli yardım eden (DY) grup $304\left(\bar{X}_{\text {yas }}=38.8\right)$, düzenli yardım etmeyen (DYY) grup ise $256\left(\bar{X}_{\text {yaş }}=38.5\right)$ kişiden oluşmuştur. Hiçbir annenin çalışmanın yapıldığı dönemde ileri yaşa bağlı bakım ihtiyacı olmaması araştırmaya katılma kriteri olarak dikkate alınmıştır.

\section{Veri toplama araçları}

Yetişkin Bağlanma Skalası (YBS) (Cicirelli, 1991, 1995), yetişkin bireyin ebeveynine bağlanma düzeyini değerlendirmeyi amaçlayan; güvenli bağlanmanın 4 tanımlayıcı özelliği olan güvenlik arayışı, ayrılık stresi, fiziksel yakınlıktan keyif alma, sevgi ve yakınlık hissi boyutları temel alınarak oluşturulmuş 16 maddelik, 7 noktalı Likert tipi bir ölçektir. Orijinal çalışmada, açımlayıcı faktör analizi 2 boyut ortaya koymuş ancak, bu boyutların önemli düzeyde örtüşmesi nedeniyle ölçek tek boyut olarak kabul edilmiştir. Güvenirliği düşük olan bir maddenin çıkarılmasıyla YBS, 15 maddelik tek boyutlu bir ölçek olarak sunulmuştur. Ölçeğin geçerliği kapsamında sevgi $(r=.73)$, güven $(r=.60)$ ve kişilerarası çatışma $(r=-.28)$ kavramlarıyla ilişkisi desteklenmiştir. Ayrıca, YBS ile değerlendirilen bağlanma düzeyinin, sevgi, güven ve kişilerarası çatışma düzeyinden daha güçlü olarak anneye yardım etme davranışlarını yordadığı da gösterilmiştir. Ölçeğin iç tutarlık katsayısı .95, bir yıllık test-tekrar test güvenirliği ise .73 olarak tespit edilmiştir.

Anne-Yetişkin Kız Ölçeği (AYKÖ) (Rastogi, 2002), yetişkin kızların anneleriyle bugünkü ilişkilerini kültürel farklılıkları da dikkate alarak değerlendirmeyi hedefleyen, 18 maddelik, 5 noktalı Likert tipi bir ölçektir. Türkçe uyarlaması yapılan AYKÖ (Onaylı, Erdur-Baker, \& Aksöz, 2010), "Bağl1lı" ve "Hiyerarşiye Güven" olarak 2 alt ölçekten oluşmaktadır. Test-tekrar test güvenirlik katsayısı .90 , iç tutarlık katsayısı ise "Bağlılık" alt ölçeği için .88, "Hiyerarşiye Güven" alt ölçeği içinse .87 olarak belirtilmiştir. 
Bağlanma ağı ve bu ağa dahil olan kişilerin hiyerarşik pozisyonunu değerlendirmeyi hedefleyen KİME ölçeği (Fraley \& Davis, 1997; Hazan \& Zeifman, 1994; Trinke \& Bartholomew, 1997), bağlanmanın fiziksel yakınlık arayışı (FY), güvenli sığınak (GS) ve güvenli üs (GÜ) işlevini temel alan 6 maddeden oluşmaktadır. Her madde için önem sırasına göre dört kişinin sıralanması beklenmektedir. Puanlar 1 (listelenen son kişi) ila 4 (listelenen ilk kişi) arasında değişmekte ve yüksek puan, listelenen kişinin bağlanma hiyerarşisindeki önceliğine işaret etmektedir. Puanlar hem bağlanma işlevleri için ayrı olarak hem de toplam puan olarak hesaplanabilmektedir. Ölçeğin Türkçe uyarlaması yapılmış (GündoğduAktürk, 2010) ve iç tutarlık katsayısı .85 - .90 aralığında rapor edilmiştir.

\section{Işlem}

Bu çalışma, 2014-2017 yılları arasında TÜBİTAK tarafından desteklenen bir proje kapsamında yapılmıştır. Çalışma öncesi gerekli etik kurul onayı alınmıştır.

YBS' nin (Cicirelli, 1995) Türkçe çevirisi, her iki dile hakim uzmanlarca, çeviri ve geri-çeviri yöntemiyle yapılmıştır. Ölçek, aşırı uç değerlere yığılmayı önlemek amacıyla 5 noktalı Likert tipi olarak düzenlenmiştir.

\section{Sonuç ve Tartışma}

Çalışmada ilk olarak YBS'nin faktör yapısı, Temel Bileşenler Analizi ile DY grubunda $(\mathrm{N}=304)$ test edilmiştir. Özdeğeri 1'den büyük olan 2 faktör yapısı gözlemlenmiştir. Özdeğerlerin çizgi grafik dağılımı ve madde dağılımının kuramsal tutarlılığı dikkate alınarak 2 faktörlü çözümlemenin uygunluğuna karar verilmiştir. İki maddenin çapraz yükleme ve çoklu bağlantı nedeniyle çıkarılması sonrasında, toplam 13 madde için 2 faktörlü yapı, eğik rotasyon ile tekrar test edilmiştir. Açıklanan varyans tüm ölçek için \%71.86, birinci faktör ( 7 madde) için \%64.3, ikinci faktör (6 madde) için ise \%7.53 olarak tespit edilmiştir (Tablo1). Madde dağılımları incelendiğinde birinci faktörün altında, tehdit/tehlike olmadığı anlarda hissedilen içselleştirilmiş güvenlik hissiyle ilgili maddelerin (örn., Annemle birlikte olduğum zaman güvenebileceğim biri ile birlikte olduğumu hissederim) toplandığ1 görülmüş ve bu faktör 'Güvenli Üs' (GÜ) olarak isimlendirilmiştir. İkinci faktörde ise tehlike anında aktif destek arayışıyla ilişkili maddelerin (örn., Bir zorluk yaşadığımda konuşmak istediğim ilk kişi annemdir) toplandığı görülmüş ve bu faktör de "Güvenli Sığınak" (GS) olarak isimlendirilmiştir.

DY grubunda elde edilen ölçek yapısının, DYY grubunda doğrulanması ve ölçüm değişmezliğinin test edilmesi amacıyla Doğrulayıcı Faktör Analizi yapılmıştır. Global uyum iyiliği gösterge değerlerine göre, verinin ilk modele iyi uyum göstermediği bulunmuştur $\left(\chi^{2}(64)=215.52 \mathrm{p}<.01, \chi^{2} / \mathrm{sd}=3.37\right.$, $\mathrm{GFI}=.88, \mathrm{AGFI}=.84, \mathrm{CFI}=.94, \mathrm{TLI}=.93, \mathrm{RMSEA}=.09)$. Modifikasyon göstergeleri doğrultusunda yapılan düzenleme sonucunda verinin modele kabul edilebilir düzeyde uyum sağladığı bulunmuştur $(\chi$ ${ }^{2}(59)=232.92, \mathrm{p}<.01, \chi^{2} / \mathrm{sd}=3.9$, GFI $=.94$, AGFI $=.90$, CFI $=.96$, TLI $=.95$, RMSEA $\left.=.07\right)$. Doğrulayıcı faktör analizi sonucunda elde edilen bu modelin DYY ve DY grupları için değişmezliği, çoklu grup analizi ile test edilmiştir. Metrik, ölçek ve katı değişmezlik modellerinin biçimsel değişmezlik modelinden anlamlı düzeyde farklı olmadığı tespit edilmiştir. Elde edilen uyum istatistikleri ve uyum katsayılarına ait fark değerleri Tablo 2'de sunulmuştur.

Açımlayıcı ve doğrulayıcı faktör analizler sonucunda, 2 boyutlu 13 maddelik bir ölçek olarak yapılandırılan YBS'nin tüm ölçek için iç tutarlık katsayısı .95, YBS-GÜ için .94 ve YBS-GS için .89 olarak tespit edilmiştir. YBS'nin test tekrar-test güvenirliği 6 ay arayla yapılmış ve YBS-GÜ için .75, YBS-GS için . 69 ve toplam puan için .78 olarak tespit edilmiştir.

Yakınsak geçerliği destekler nitelikte, YBS'nin anneyle iletişime geçme sıklığı $(r=.37-.40)$, ilişki tatmini $(r=.54-.58)$, yakınlık hissi $(r=.55-.60)$, AYKÖ-Bağl1lık $(r=.69-.74)$ ve AYKÖ-Hiyerarşiye Güven $(r=.48$ - .66) ile pozitif yönde anlamlı ilişkisi gösterilmiştir. Ayrıca, eş zaman geçerliğini destekler nitelikte YBS'nin, bağlanmada hiyerarşi önceliğini değerlendiren KİME'nin tüm alt boyutlarıyla anlamlı, pozitif ve tutarlı ilişki tespit edilmiştir. Buna ek olarak, YBS-GÜ'nün KİME-GÜ $(r=.45)$ ile korelasyon katsayısının KIME-GS $(r=.35)$ ve KIME-FY'ye $(r=.33)$ kıyasla görece daha 
yüksek olduğu, benzer şekilde YBS-GS'nin KİME-GS $(r=.54)$ ve KİME-FY $(r=.56)$ ile korelasyon katsayısının KİME-GÜ'ye $(r=.35)$ kıyasla görece daha yüksek olduğu dikkat çekmiştir.

Sonuç olarak, yetişkin kızların yaşlanmakta olan annelerine bağlanma düzeylerini değerlendiren YBS Türkçe versiyonunun geçerliği ve güvenirliği ampirik olarak desteklenmiştir. Birbiriyle ilişkili 2 alt ölçekten oluşan YBS-Türkçe, yetişkin kız için annenin güvenli üs ve sığınak olarak önemini vurgulamak amacıyla ayrı puanlanabildiği gibi, annenin güvenli bağlanma figürü olarak önemini vurgulamak amacıyla toplam puan olarak da değerlendirilebilmektedir. Yaşlanan dünya nüfusu, hızla değişmekte olan aile yapısı ve dinamikleri, yaşanan sosyodemografik değişimlere yönelik öngörülen riskler, yaşlanan ebeveyn ve yetişkin çocuğun yaşam boyu devam eden ilişkilerinin duygusal niteliği ve bağlanma dinamiklerine yönelik alan yazındaki sınırlı bilgi dikkate alındığında, YBS'nin bu alandaki çalışmaların artmasına öncü olacağı ve önemli bilgilerin elde edilmesi için değerli bir araç olacağı düşünülmektedir. 